\title{
CELL COUNTS OF NORMAL AND OSTEO-ARTHRITIC ARTICULAR CARTILAGE IN RELATION TO THE UPTAKE OF SULPHATE $\left({ }^{35} \mathrm{SO}_{4}\right)$ IN VITRO
}

\author{
BY \\ G. MEACHIM AND D. H. COLLINS \\ From the Department of Pathology, University of Sheffield
}

Studies previously reported have demonstrated an increased utilization of sulphate by human articular cartilage in osteo-arthritis (McElligott and Collins, 1960; Collins and McElligott, 1960), a phenomenon that is not a direct consequence of ageing (Collins and Meachim, 1961). The results of radiochemical assay were expressed in terms of the amount of sulphate fixed by a unit weight of dried cartilage ( $\mu$ g. per g.). The utilization of sulphate is a function of the cartilage cells and a measure of their ability to synthesize sulphated mucopolysaccharides, presumably chondroitin sulphate. The technique employed is designed to exclude any exchange of the labelled sulphate $\left({ }^{35} \mathrm{SO}_{4}\right)$ with pre-existing sulphated matrix, and autoradiographs repeatedly confirmed the localization over chondrocytes of sulphate from the test medium. Interest is therefore attached to the cellularity of the cartilage tested, just as Bywaters (1937), in studying the glycolytic respiration of cartilage, emphasized that account must be taken not only of the weight of the tissue investigated, but also of its cell population.

\section{Material and Methods}

Samples of articular cartilage from the knee joint (patella) and the shoulder joint (humerus) were obtained at $\mathbf{4 5}$ autopsies on persons ranging in age from 25 to 82 years. The time between death and autopsy in no case exceeded 25 hours, and previous experience informs us that the chondrocytes retain for this period much of their vitality and their ability to synthesize mucopolysaccharide.

Details of the radiochemical and autoradiographic techniques have been given in our previous articles.

Technique of Cell Count in Cartilage.-This was based on the counting of nuclei in defined areas of stained paraffin sections and is recorded as numbers of nuclei per $1 / 16$ sq. mm. After excluding certain cartilages which were covered by fibrous pannus resulting from a rheumatoid pattern of arthritis, there remained 43 specimens of cartilage from the humerus and 37 from the patella on which satisfactory counts were completed.
Each block of cartilage was sectioned in the same anatomical plane and cut on the same microtome, set for $7 \mu$ sections. It is well known, however, that a constant microtome setting does not guarantee sections of constant thickness in the ribbon obtained. Conclusions have therefore been based on comparison of different areas of the same section, or on average figures obtained from all the cartilage specimens in each group.

After Meyer's haematoxylin staining, the sections were studied by a monocular microscope fitted with a diaphragm which exposed a square field of the section of constant size $(0.25 \times 0.25 \mathrm{~mm}$.). A count was made of the total number of nuclei seen in each field examined.

All counts were performed by one observer. The counts were made along the entire length of cartilage strips, one field wide, running perpendicularly from the articular surface to the line of calcification. Such strips were selected for counting at regular intervals along the section of cartilage. At least eighty fields were counted in each section, and the average nuclear count was taken as a guide to the overall cellularity of the cartilage specimen. The chondrocytes of the calcified zone were not included in the overall counts, as autoradiography has shown them to be virtually inactive in sulphate fixation.

The average nuclear count was also determined separately for the two regions of each cartilage:

(a) The Superficial Region.-This comprises the $0.25 \mathrm{~mm}$. band of cartilage immediately below the articular surface, and in the intact healthy cartilage approximates to Zone 1 of Collins and McElligott (1960). The superficial zone had, of course, completely disappeared from a part or the whole of the cartilage in many of the samples from osteo-arthritic joints.

(b) The Sulphate-fixing Region.-This comprises the cartilage between the lower border of the superficial region and the upper border of the calcified area, and approximates to Zones 2 and 3 of Collins and McElligott (1960). This region ranged from 0.75 to $4.75 \mathrm{~mm}$. in depth, the cartilage of the intact patella generally being two to four times thicker than that of the humerus. Erosion extended into this region in many of the osteoarthritic patella specimens.

Autoradiography has shown that the cells of Zones 
2 and 3 are more active in sulphate fixation than those of the superficial Zone 1 (Collins and McElligott, 1960; Collins and Meachim, 1961). It was for this reason that nuclear counts were determined separately for the superficial and for the sulphate-fixing regions.

In osteo-arthritis the nuclear count in fibrillated areas was compared with that of non-fibrillated areas at the same depth in the same section when this was possible. The amount of chondrocyte clumping in the deeply fibrillated areas was noted.

Autoradiographs were all exposed in the dark at $4^{\circ}$ C. for 6 weeks.

Grading of Osteo-Arthritis.-This followed that proposed by Collins (1949) and was based on naked-eye inspection of the joint surfaces supplemented by microscopical examination of the cartilage section.

Grade 0: Smooth cartilage surface.

Grade I: Fibrillation of cartilage limited to the superficial zones of tangential and oblique fibres.

Grade II: Fibrillation extending into the deep zone of vertical fibres, but no denudation of bone.

Grades $I I I$ and $I V$ : Deep fibrillation with loss of cartilage exposing bare bone at one or more areas.

\section{Results}

\section{Distribution of Cells in Normal Cartilage}

The nuclear count of the intact superficial zone, extending to a depth of $0.25 \mathrm{~mm}$. from the articular surface, was usually two to three times greater than that of the sulphate-fixing zones in both humerus and patella cartilages (Table I). In the absence of osteo-arthritis, a few empty lacunae without nuclei were seen in the superficial zone of some cartilages. These probably represent effete cells, which appear functionless in the autoradiographs. Since the nuclei were absent they were not counted as cells.

$$
\text { TABLE I }
$$

CELL COUNTS (nuclei per $1 / 16$ sq. mm.) OF SUPERFICIAL AND SULPHATE-FIXING DEEPER ZONES OF ARTICULAR CARTILACIE OF HUMERUS ACCORDING TO AGE AND GRADE OF OSTEO-ARTHRITIS

\begin{tabular}{|c|c|c|c|c|}
\hline \multirow{2}{*}{$\begin{array}{l}\text { Grade of } \\
\text { Osteo- } \\
\text { Arthritis }\end{array}$} & \multirow{2}{*}{$\begin{array}{c}\text { Age } \\
\text { Range } \\
\text { (yrs) }\end{array}$} & \multirow{2}{*}{$\begin{array}{l}\text { No. } \\
\text { of } \\
\text { Cases }\end{array}$} & \multicolumn{2}{|c|}{$\begin{array}{l}\text { Average Cells per Field } \\
(1 / 16 \text { sq. } \mathrm{mm} .)\end{array}$} \\
\hline & & & $\begin{array}{c}\text { Superficial } \\
\text { Zone }\end{array}$ & $\begin{array}{l}\text { Sulphate-fixing } \\
\text { Zones }\end{array}$ \\
\hline $\begin{array}{l}0 \\
0 \\
0 \\
\mathbf{I}\end{array}$ & $\begin{array}{c}25-44 \\
45-64 \\
65-84 \\
\text { All ages }\end{array}$ & $\begin{array}{r}9 \\
14 \\
9 \\
10\end{array}$ & $\begin{array}{l}27 \\
26 \\
27 \\
19\end{array}$ & $\begin{array}{l}10 \\
12 \\
12 \\
11\end{array}$ \\
\hline
\end{tabular}

\section{Grade I Osteo-arthritis}

This was best studied in the humerus where only one cartilage was encountered with fibrillation $\overrightarrow{\bar{\rho}}$ extending more deeply than the superficial zone. Table I shows that the early cartilage lesion was accompanied by a loss of cells from the flaking $\frac{\omega}{\omega}$ superficial zone and histological sections showed no $\widehat{\nabla}$ tendency for these chondrocytes to proliferate or clump. No important alteration in the cellularity os of the deep zones of cartilage was noted at this $\overrightarrow{0}$ stage.

\section{Grades II to IV Osteo-arthritis}

Only the patella specimens showed cartilage changes of this severity. Fibrillation extending into the radial and deeper fibre zones of articular cartilage is accompanied by the appearance of $\mathrm{cr}$ clumps of chondrocytes near the cracks in the $\frac{\text { ? }}{3}$ matrix (Fig. 1, opposite). The activity of these cells in fixing sulphate, i.e. synthesizing chondroitin sulphate, is clearly shown in the autoradiographs $\stackrel{\widehat{S}}{\underline{T}}$ (Fig. 2, opposite).

When the nuclei are counted it is apparent (Table $\overrightarrow{\mathscr{C}}$ II) that the cell clumps represent a proliferation of ? chondrocytes and not merely their redistribution. The larger the clumps, the more numerous are the cells within the deeper zones of cartilage. In all but two specimens (Cases R22 and R8) the deeply fibrillated areas were populated by more cells than $\stackrel{\mathbb{Q}}{\complement}$ were present in non-fibrillated areas of cartilage $\overrightarrow{\vec{D}}$ lying at a corresponding depth in the section $\frac{0}{3}$ (Table II).

\section{TABLE II}

CELL COUNTS (nuclei per 1/16 sq. mm.) IN CARTILAGE OF PATELLA IN GRADES II-IV OSTEO-ARTHRITIS. EFFECT OF CHONDROCYTE CLUMPS IN AREAS OF FIBRILLATION. COMPARISON WITH NON-FIBRILLATED AREAS AT THE SAME DEPTH AND IN THE SAME SECTION

\begin{tabular}{|c|c|c|c|}
\hline \multirow{2}{*}{$\begin{array}{l}\text { Case } \\
\text { No. }\end{array}$} & \multirow{2}{*}{$\begin{array}{l}\text { Chondrocyte } \\
\text { Clumps }\end{array}$} & \multicolumn{2}{|c|}{$\begin{array}{l}\text { Average Cells per Field } \\
(1 / 16 \mathrm{sq} . \mathrm{mm} .)\end{array}$} \\
\hline & & $\begin{array}{c}\text { In Fibrillated } \\
\text { Areas }\end{array}$ & $\begin{array}{c}\text { In Non-fibrillated } \\
\text { Areas }\end{array}$ \\
\hline $\begin{array}{l}\text { R35 } \\
\text { R22 } \\
\text { R36 }\end{array}$ & $\begin{array}{l}\text { Small } \\
\text { Small } \\
\text { Small }\end{array}$ & $\begin{array}{l}8 \\
9 \\
8\end{array}$ & $\begin{array}{r}4 \\
10 \\
4\end{array}$ \\
\hline $\begin{array}{l}\text { R40 } \\
\text { R21 } \\
\text { R11 } \\
\text { R } 5 \\
\text { R } 8 \\
\text { R26 }\end{array}$ & $\begin{array}{l}\text { Medium } \\
\text { Medium } \\
\text { Medium } \\
\text { Medium } \\
\text { Medium } \\
\text { Medium }\end{array}$ & $\begin{array}{r}10 \\
13 \\
17 \\
15 \\
9 \\
13\end{array}$ & $\begin{array}{r}6 \\
12 \\
7 \\
12 \\
9 \\
7\end{array}$ \\
\hline 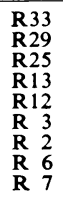 & $\begin{array}{l}\text { Large } \\
\text { Large } \\
\text { Large } \\
\text { Large } \\
\text { Large } \\
\text { Large } \\
\text { Large } \\
\text { Large } \\
\text { Large }\end{array}$ & $\begin{array}{l}19 \\
15 \\
16 \\
12 \\
11 \\
19 \\
18 \\
18 \\
15\end{array}$ & $\begin{array}{r}7 \\
9 \\
10 \\
8 \\
9 \\
9 \\
14 \\
10 \\
9\end{array}$ \\
\hline
\end{tabular}


Fig. 1.-Multicellular clusters in deeply fibrillated articular cartilage from the patella of a woman aged 68 years. Haematoxylin $\times 125$.
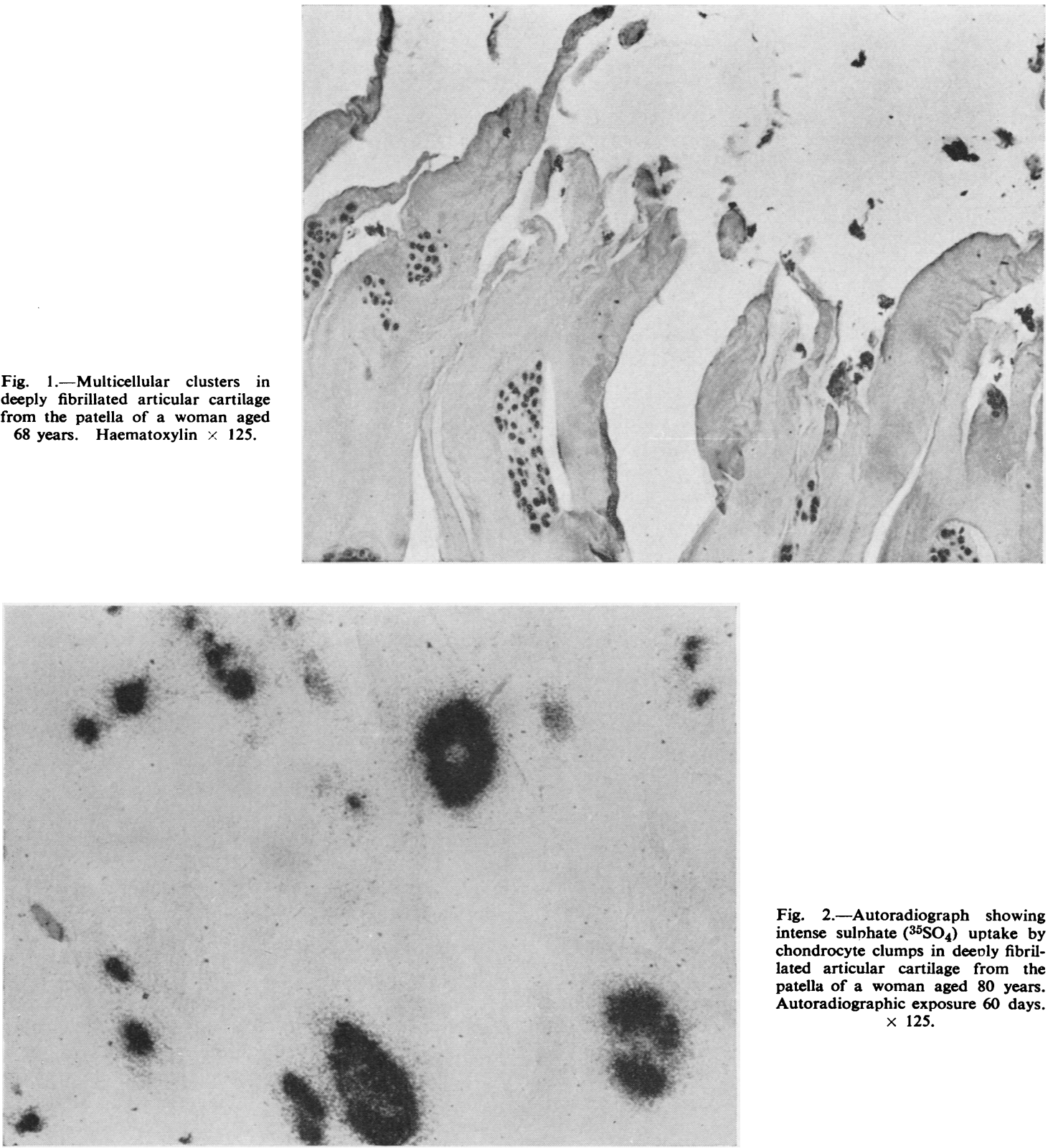

Fig. 2.-Autoradiograph showing intense sulphate $\left({ }^{35} \mathrm{SO}_{4}\right)$ uptake by chondrocyte clumps in deeply fibrillated articular cartilage from the patella of a woman aged 80 years. Autoradiographic exposure 60 days. $\times 125$.

In Table III the average nuclear count of the sulphate-fixing zones of the patella is shown according to the grade of osteo-arthritis. Local increase in the cellularity of deeply fibrillated areas is reflected by a moderate increase in the cell count of the whole cartilage with increasing severity of osteo-arthritis. However, the effect of the localized increases in cellularity is modified by the persistence of a good deal of intact cartilage in the sulphate-fixing zones of many of the elsewhere deeply fibrillated specimens.

Table III (overleaf) also shows that the overall cell counts of cartilages, increasing with the degree of osteo-arthritis, move more or less in parallel with the increase of sulphate utilization by these cartilages as assayed radiochemically. 
TABLE III

CELL COUNTS (nuclei per $1 / 16$ sq. mm.) OF ARTICULAR CARTILAGE OF PATELLA ACCORDING TO GRADE OF OSTEO-ARTHRITIS COMPARED WITH SULPHATE UTILIZATION ( $\mu \mathrm{g} . / \mathrm{g}$. of $\mathrm{SO}_{4}{ }^{\prime \prime}$ ) MEASURED RADIOCHEMICALLY

\begin{tabular}{|c|c|c|c|c|c|}
\hline \multirow{2}{*}{$\begin{array}{l}\text { Grade } \\
\text { of } \\
\text { Osteo- } \\
\text { arthritis }\end{array}$} & \multirow[t]{2}{*}{$\begin{array}{l}\text { No. } \\
\text { of } \\
\text { Cases }\end{array}$} & \multicolumn{2}{|c|}{$\begin{array}{c}\text { Cell Counts per Field } \\
\text { (1/16 sq. mm.) } \\
\text { of Sulphate-fixing } \\
\text { Zones of Cartilage }\end{array}$} & \multicolumn{2}{|c|}{$\begin{array}{c}\mathrm{SO}_{4}^{\prime \prime} \text { Uptake } \\
(\mu \mathrm{g} . / \mathrm{g} .)\end{array}$} \\
\hline & & Average & Range & Average & Range \\
\hline $\begin{array}{c}\mathbf{0} \\
\text { I } \\
\text { III } \\
\text { III-IV }\end{array}$ & $\begin{array}{r}5 \\
7 \\
14 \\
7\end{array}$ & $\begin{array}{r}6 \cdot 8 \\
9 \cdot 0 \\
9 \cdot 7 \\
11 \cdot 0\end{array}$ & $\begin{array}{l}6-8 \\
6-12 \\
5-14 \\
7-16\end{array}$ & $\begin{array}{l}0 \cdot 720 \\
0 \cdot 894 \\
1 \cdot 081 \\
1 \cdot 290\end{array}$ & $\begin{array}{l}0 \cdot 126-1 \cdot 039 \\
0 \cdot 212-1 \cdot 811 \\
0 \cdot 366-1 \cdot 925 \\
0 \cdot 569-2 \cdot 278\end{array}$ \\
\hline
\end{tabular}

\section{Discussion}

The first conclusion from our results is that in the earliest stage of the cartilaginous lesion of osteoarthritis, the cells of the superficial zone of cartilage as it flakes away do not proliferate, neither do they clump. Previous observations (Collins and McElligott, 1960) had shown that these cells failed to react by synthesizing sulphated mucopolysaccharides. They are, as far as we have determined, effete.

The second point emerging from our studies is the confirmation, by actually counting cell nuclei over considerable areas of fibrillated cartilage, that the clumps of chondrocytes appearing near the fissures are the result of cellular proliferation and not merely of the redistribution of a numerically stable cell population (Table II). The absence of cellular mitosis in osteo-arthritic cartilage has been commented upon by many. We, too, have seen no convincing mitotic figures. This does not conflict with the view that proliferation of cartilage cells does take place. Firstly, the lesion of osteo-arthritis is one of very slow evolution and the cellular activity of cartilage in this disease is of a very different order from that seen at, say, the epiphyseal growth line where cartilage-cell mitoses are easy to find. Secondly, our cartilage specimens were collected in the post mortem room some hours after death, and it is possible that in any post mortem tissue mitotic cycles that have begun complete themselves in the time between somatic death and tissue fixation, and that new cycles are not initiated (Ghadially, 1961).

The chondrocyte clumps seen in the deeply fibrillated cartilage of human osteo-arthritis show intense sulphate utilization on autoradiography (Figs 1 and 2). Histochemical studies demonstrate a pool of sulphated mucopolysaccharide in and around the clumps, in contrast to the loss of mucopolysaccharide from the intervening matrix. From these findings it has been deduced that the more deeply situated chondrocytes react to matrix loss by increased mucopolysaccharide synthesis (Collins $\square$ and McElligott, 1960). Our observations indicate that chondrocyte proliferation is a further feature $\overrightarrow{\vec{F}}$ of this reactive phenomenon. Table III shows that $\stackrel{\text { ? }}{+}$ the increase in cell numbers and the increase in $\frac{\mathrm{C}}{0}$ sulphate utilization move in a more or less parallel $\frac{\bar{\sigma}}{\bar{\omega}}$ fashion. It appears, therefore, that the increase $\frac{{ }^{\circ}}{\vec{D}}$ of sulphate utilization, and thereby of chondroitin- $\varrho$ sulphate synthesis, is related in some measure to $\%$ an increased proliferation of cartilage cells. We $\vec{\circ}$ must emphasize, however, that, while this relationship can be shown when the average numerical $\vec{\omega}$ results of groups of cases are considered, as in Table III, considerable discrepancies appear when $\frac{2}{2}$ individual cases are compared. The ranges of ${ }_{-}$ results in Table III give some indication of this. Here it will be seen that the measurements of $i \vec{c}$ sulphate uptake are more wide-ranging than the cell $\mathrm{O}$ counts. Low uptakes did not necessarily correspond with low cell counts in any of the groups of cases. $\bar{z}$ It is, of course, true that the cell count is a more stable character of a tissue than its metabolic $\stackrel{\sim}{\mathcal{S}}$ activity, but Collins and Meachim (1961) found that, $\vec{\odot}$ in the present series of cartilage samples studied up to 25 hours after death, no statistical relationship existed between the interval of time between death 0 and the collection of the cartilage and the results of the individual radiochemical assays. It seems to us, $\bar{\partial}$ therefore, that there may be a genuine biological $\frac{\otimes}{\varnothing}$ variation in degree of metabolic activity of the $\stackrel{\square}{\square}$ "average cell" of different cartilages. The cartilage $\overrightarrow{\overrightarrow{0}}$ cells of animals are known to increase their individual 3 sulphate-fixing activity in certain experimental situations (Carlson, 1957; McElligott and Potter, 1960), but we have been unable to obtain quantitative data on this point in our human post mortem material.

Ageing produced no obvious effect on the cellu- $\stackrel{\delta}{\circ}$ larity of intact cartilage from the upper end of the adult humerus (Table I). This is in line with the 음 results of our quantitative assays of sulphate $D$ fixation in vitro, which failed to demonstrate a을. direct effect of ageing alone on the sulphate uptake $\bar{N}$ of adult cartilage from this site (Collins and $O$ Meachim, 1961). These results at first sight appear $N$ inconsistent with those of Wagoner, Rosenthal, and $\underset{\mathrm{W}}{\mathrm{N}}$ Bowie (1941) who studied the effect of ageing on the cellularity and metabolic activity of bovine foot articular cartilage. They found that cellular density decreased rapidly during the first year of life, and $\stackrel{\oplus}{+}$ then more slowly as the adult cartilage aged. The 0 rate of oxygen consumption per cell also decreased, $\overrightarrow{0}$ although the rate of glucose splitting and hydrogen mobilization per cell showed little alteration. $\frac{\mathbb{D}}{\mathbb{Q}}$ These authors state, however, that the older cattle 
showed "degenerate" cartilage changes, as observed by Bauer and Bennett (1936). These results are not therefore relevant to the study of the effect of ageing on healthy and intact adult cartilage, although they are in line with the observation of Bywaters (1937) that juvenile cartilage is more cellular than that of the adult.

\section{Summary}

Cell counts have been made of the various zones of human articular cartilage obtained post mortem from the knee joint (patella) and the shoulder joint (humerus).

In normal cartilage, the superficial zone $(0.25 \mathrm{~mm}$. in depth) contains two or three times as many cells per unit area as the deeper zones. The superficial cells often appear effete and generally show no ability to synthesize chondroitin sulphate. The deeper zones are therefore referred to as the sulphatefixing zones.

There is loss of cells from the flaking superficial zone in the early cartilage lesion of Grade I osteoarthritis; the cells that remain show no tendency to proliferate.

In the more advanced grades of osteo-arthritis, when fibrillation extends into the deeper zones, the chondrocytes in the damaged areas of cartilage increase numerically, in comparison with the cells of the non-fibrillated areas of the same cartilage. The phenomenon of cell clumping near the fissures seems to be due to proliferation and not mere redistribution of chondrocytes.

There is an overall increase in density of cell population in the sulphate-fixing deeper zones of osteo-arthritic as compared with normal cartilages. The cell counts move more or less in parallel with the increase of sulphate utilization by these cartilages when groups of cases are compared, and it is probable that the increase of chondroitin-acid synthesis previously observed in osteo-arthritis is related in some measure to chondrocyte proliferation. A much wider variation in sulphate utilization than in cell-count has, however, been observed, suggesting that different cartilages display a wide range of metabolic activity.

Age, alone, without the association of osteoarthritis, causes no change in the cellularity of adult cartilage.

The work here reported was performed with the aid of a research grant from the Empire Rheumatism Council for which we are very grateful.

\section{REFERENCES}

Bauer, W., and Bennett, G. A. (1936). J. Bone Jt Surg., $18,1$.

Bywaters, E. G. L. (1937). J. Path. Bact., 44, 247.
Carlson, H. (1957). Acta orthop. scand., Suppl. 28.

Collins, D. H. (1949). "The Pathology of Articular and Spinal Diseases", p. 76. Arnold, London.

_- and McElligott, T. F. (1960). Ann. rheum. Dis., 19, 318.

— and Meachim, G. (1961). Ibid., 20, 117.

Ghadially, F. N. (1961). J. Path. Bact., 81, 169.

McElligott, T. F., and Collins, D. H. (1960). Ann. rheum. Dis., 19, 31.

- and Potter, J. L. (1960). J. exp. Med., 112, 743.

Wagoner, G., Rosenthal, O., and Bowie, M. A. (1941). Amer. J. med. Sci., 201, 489.

Formule cellulaire du cartilage articulaire normal et ostéoarthritique par rapport á l'absorption de sulfate $\left({ }^{35} \mathrm{SO}_{4}\right)$ in vitro

\section{RÉSUMÉ}

On a procédé à la numération des cellules dans de différentes zones du cartilage humain obtenu à l'autopsie de l'articulation du genou (rotule) et de l'épaule (humérus).

Dans le cartilage normal, la zone superficielle $(0,25$ $\mathrm{mm}$. en profondeur) contient deux ou trois fois plus de cellules par unité de surface que les zones plus profondes. Les cellules superficielles ont souvent une apparence caduque et, habituellement, ne semblent pas capables de former du sulfate de chondroïtine. Par conséquent, quand on parle de zones de fixation de sulfate, il s'agit de zones plus profondes.

Dans les lésions cartilagineuses jeunes d'ostéoarthrite du I-er degré il y a une perte de cellules de la zone superficielle qui tend à s'écailler; les cellules restantes ont peu de tendance à proliférer.

Aux stades plus avancés d'ostéoarthrite, lorsque la fibrillation s'étend aux zones plus profondes, les chondrocytes dans les parties endommagées du cartilage deviennent plus nombreux par rapport aux cellules des parties non-fibrillées du même cartilage. Le phénomène d'agglutination des cellules près des fissures semble être dû à la prolifération et non pas à une simple redistribution des chondrocytes.

Par comparaison au cartilage normal, on trouve une augmentation générale de la densité de la population cellulaire dans les zones plus profondes du cartilage ostéoarthritique, fixant le sulfate. La formule cellulaire correspond plus ou moins à l'utilisation de sulfate par ces cartilages lorsqu'on compare des groupes de cas, et il est probable que l'augmentation de la synthèse de la chondroïtine-acide, observée antérieurement dans l'ostéoarthrite, est associée jusqu'à un certain point à la prolifération chondrocytaire. On a, toutefois, observé de plus amples variations dans l'utilisation de sulfate que dans la formule cellulaire, indiquant que de différents cartilages ont une grande étendue d'activité métabolique.

L'âge seul, sans ostéoarthrite associée, n'affecte pas la formule cellulaire du cartilage adulte.

Fórmula celular del cartílago articular normal y osteoartritíco en relación con la absorpción de sulfato $\left({ }^{5} \mathrm{SO}_{4}\right)$ in vitro

\section{SUMARIO}

Se hicieron recuentos de células en diferentes zonas del cartílago humano obtenido post mortem de las articulaciones de la rodilla (rótula) y del hombro (húmero). 
En el cartílago normal, la zona superficial $(0,25 \mathrm{~mm}$. de profundidad) contiene dos o tres veces más células por unidad de superficie que las zonas más hondas. Las células superficiales a menudo presentan una apariencia gastada y, generalmente, no pueden sintetizar sulfato de condroitina. Así pués, las zonas de fijación de sulfato son realmente las zonas más hondas.

En las lesiones cartilaginosas tempranas de osteoartritis del primer grado se ve una perdida de células de la zona escamosa superficial; las demás células tienen poca tendencia a proliferar.

En osteoartritis de un grado mayor, cuando la fibrilación se extiende a zonas más profundas, los condrocitos en partes lesionadas del cartílago aumentan númericamente en comparación con las células de las partes del mismo cartílago sin proliferación de fibrillas. El fenómeno de aglutinación de células cerca de fisuras parece ser debida a la proliferación y no a una simple redistribución de condrocitos.

En comparación con el cartílago normal, se nota un aumento general de la densidad de la población celular $\overrightarrow{\vec{F}}$ en las zonas más hondas del cartílago osteoartrítico que fija el sulfato. La fórmula celular va más o menos paralelamente al aumento de utilización de sulfato por estos cartílagos cuando se compara grupos de casos, y es probable que el aumento de la síntesis del ácido de condroitina, observado anteriormente en la osteo- $\varrho$ artritis, está asociado en cierta medida a la proliferación @ొ condrocitaria. Se observaron, sin embargo, mayores variaciones en la utilización de sulfato que en la fórmula $\vec{\circ}$ celular, indicativas de gran amplitud de la actividad metabólica de diferentes cartílagos.

La edad sola, sin osteoartritis asociada, no afecta la fórmula celular del cartílago adulto. 